4.3. Kết quả các thang điểm. Theo kết quả nghiên cứu, các thang điểm lâm sàng đều có mối tương quan ý nghĩa với $X Q$ sọ bên và hoặc nội soi mũi, tuy nhiên độ chính xác của các thang điểm lâm sàng không được chứng minh rõ ràng do sự đa dạng của các phương pháp đánh giá, cõ mẫu khác nhau, các biến triệu chứng thay đổi. Trong đó, hai bài báo sử dụng thang điểm NOI có nhược điểm là chỉ đánh giá triệu chứng ban ngày mà bỏ qua triệu chứng ban đểm rất có ý nghĩa ở trẻ. Bên cạnh đó, chúng tôi nhận định rằng VA quá phát là một bệnh ít rủi ro cấp tính và nội soi chẩn đoán thường có sẵn nên độ nhạy thấp 22-78\% chấp nhận được bởi cùng với đó độ âm tính giả cao hơn; độ đặc hiệu cao $>88 \%$ cho thấy độ tin cậy của thang điểm, vì vậy có thể sử dụng thang điểm lâm sàng như 1 test sàng lọc bệnh.

Khi so sánh các nghiên cứu được lựa chọn, có một số hạn chế còn tồn tại. Đầu tiên, các nghiên cứu đã sử dụng 2 phương pháp đánh giá kết quả, kể cả khi sử dụng tiêu chuẩn vàng là nội soi tai mũi họng nhưng quy trình cũng không được chuẩn hóa. Thứ hai, chỉ có $3 / 10$ nghiên cứu đánh giá giá trị của các thang điểm lâm sàng. Cuối cùng, vì thiết kế nghiên cứu là tổng quan luận điểm, nên chúng tôi không đánh giá chất lượng của các bài báo đâu vào. Mặc dù vậy, các thang điểm lâm sàng đều đơn giản, cách chấm điểm kết quả rõ ràng nên dễ dàng áp dụng ở tuyến y tế cơ sở nhằm chẩn đoán sàng lọc bệnh trong cộng đồng và chỉ định phẫu thuật cho VA độ III, IV.

\section{KẾT LUẬN}

Các thang điểm lâm sàng trong nghiên cứu cho thấy 3 triệu chứng thường gặp nhất là thở miệng, ngủ ngáy, ngừng thở khi ngủ. Thang điểm lâm sàng có mối tương quan với nội soi mũi hơn Xq so bên, nhất là ở trẻ VA quá phát độ III, IV. Có thể áp dụng các thang điểm lâm sàng để chẩn đoán sàng lọc VA quá phát độ III, IV trong cộng đồng.

\section{TÀI LIÊU THAM KHẢO}

1. Pereira L, Monyror J, Almeida FT, et al. Prevalence of adenoid hypertrophy: A systematic review and meta-analysis. Sleep Med Rev. 2018;38:101-112. doi:10.1016/j.smrv.2017.06.001

2. Torretta S, Marchisio P, Succo G, Capaccio P, Pignataro L. Nasopharyngeal fiberendoscopy in children: a survey of current Italian pediatric otolaryngological practices. Ital J Pediatr. 2016;42:24. doi:10.1186/s13052-016-0234-y

3. Pagella $F$, De Amici $M$, Pusateri $A$, et al. Adenoids and clinical symptoms: Epidemiology of a cohort of 795 pediatric patients. Int J Pediatr Otorhinolaryngol. $\quad 2015 ; 79 \quad$ (12):2137-2141. doi:10.1016/ j.ijporl.2015.09.035

4. Prestes L, Neto G, Camera $M$. Adenotonsillectomy effect on the life quality of children with adenotonsillar hyperplasia. Int Arch Otorhinolaryngol. 2009;13.

5. Kindermann CA, Roithmann $R$, Lubianca Neto JF. Sensitivity and specificity of nasal flexible fiberoptic endoscopy in the diagnosis of adenoid hypertrophy in children. Int J Pediatr Otorhinolaryngol. 2008;72(1):63-67. doi:10.1016/ j.ijporl.2007.09.013

\title{
U KÝ SINH TRÙNG (SÁN DÂY LỢN) TRONG CƠ THẤT PHẢI - NHÂN MộT TRƯỜNG Hợ'P ĐIỀU TRI THÀNH CÔNG VÀ NHÌN LẠI Y VĂN
}

\author{
Phạm Hữu Lư ${ }^{1,2}$, Hoàng Trọng Hải ${ }^{2}$, Dương Hoàng Long ${ }^{2}$, \\ Phan Thùy Chi ${ }^{1,2}$, Nguyễn Tùng $S_{0} n^{2}$, Nguyễn $S \tilde{y} L^{2}{ }^{2} h^{2}$, \\ Phạm Hữu Khuyên ${ }^{2}$, Phùng Duy Hồng Sơn'², Khổng Tiển Bình'2, \\ Phạm Tiến Quân ${ }^{2}$, Nguyễn Hữu Ước ${ }^{1,2}$ \\ hoăc màng tim. Trong y văn có một số bài báo mô tả \\ thương tổn ở tim do kí sinh trùng nhưng chỉ dừng lại ở \\ những thông báo lâm sàng nhiễm ký sinh trong trong \\ đó có bênh tim do sán dây lợn. Tại bênh viện hữu \\ nghị Việt Đức: Chúng tôi thônng báo trường hợp lâm \\ sàng hiếm gặp về bệnh nhiễm sán dây lợn trong cơ \\ thất phải đã được chẩn đoán và xử trí. Phương pháp \\ nghiên cứu: Mô tả ca lâm sàng về triệu chứng lâm \\ sàng, cận lâm sàng và thái độ xử trí cho loại tổn \\ thương này. Trường hợp lâm sàng: Bênh nhân nữ 51 \\ tuổi, vào viện do khám sức khỏe định kỳ phát hiện \\ khối u vách liên thất trong buồng tâm thất phải, bệnh \\ nhân được chẩn đoán u cơ tim và có chỉ định sinh \\ thiết nhưng trong quá trình sinh thiết có biến chứng \\ thủng thành cơ tim, bệnh nhân được chỉ định phẫu
}

\section{TÓM TẮT}

Mở đâu: Bệnh kí sinh trùng là một bênh thường gặp ở các nước nhiệt đới. Bệnh này có thể có gây tổn thương ở nhiều cơ quan trong cơ thể trong đó có biểu hiên ở tim. Tim là cơ quan có thể bi ảnh hưởng trực tiểp hoặc gián tiếp, bệnh có thể biểu hiện ở cơ tim

${ }^{1}$ Đại học Y Hà Nọi

${ }^{2}$ Bềnh viên Hữu nghi Viêtt Đức

Chịu trách nhiệm chính: Phạm Hữu Lư

Email: phamhuulu@hmu.edu.vn

Ngày nhân bài: 7.6.2021

Ngày phản biên khoa hoc: 31.7.2021

Ngày duyệt bài: 9.8.2021 
thuật cấp cứu tim phổi máy, xử lý tổn thương thủng thành thất phải, cắt u cơ tim gửi làm giải phâuu bệnh cho kết quả là u sán dây lợn. Kết luận: Bệnh tim do sán dây lợn là hiếm gặp nhưng có thể gặp nên cần được nghĩ đến khi chẩn đoán một khối u cơ tim. Chẩn đoán trước mổ bằng siêu âm tim, cộng hưởng từ, xét nghiêm huyết thanh.

Từ khóa: Bệnh tim do kí sinh trùng, sán dây lợn, u tim.

\section{SUMMARY}

A CASE OF HEART PSEUDO-TUMOR BY TAPEWORM IN RIGHT VENTRICLE - SUCCESSFUL TREATMENT AND REVIEW OF LITERATURE

Introduction: Parasitic disease is a common disease in tropical countries. This disease can have damage to many organs in the body including the heart. The heart is an organ that can be affected directly or indirectly, the disease can manifest in the myocardium or pericardium. In the literature, there are a number of articles describing heart damage caused by parasites, but only clinical reports of parasitic infections, including heart disease caused by pork tapeworms, are reported. At Viet Duc University Hospital: We announce that a rare clinical case of pork tapeworm infection in the right ventricle has been diagnosed and treated. Research method: Describe the clinical case about clinical symptoms, subclinical and management attitude for this type of lesion. Clinical case: A 51-year-old female patient, admitted to the hospital by routine physical examination, discovered an interventricular septal tumor in the right ventricular chamber. Biopsy had complications of myocardial perforation, the patient was indicated for emergency cardiopulmonary surgery, treatment of right ventricular wall perforation damage, myocardial tumor resection sent for pathology, the result was a pork tapeworm. Conclusion: Heart disease caused by tapeworms is rare but possible and should be considered when diagnosing a myocardial tumor. Preoperative diagnosis by echocardiography, magnetic resonance, serological tests.

Keyword: Heart disease caused by parasites, tapeworms, heart tumors.

\section{I. ĐĂT VẤN ĐỀ}

Trong những năm gần đây, bệnh nhiễm kí sinh trùng ngày càng được quan tâm. Xu hướng hội nhập, di cư làm biến đổi dịch tễ của nhiễm kí sinh trùng, cùng với các bệnh suy giảm miễn dich, bênh truyền nhiễm, ô nhiễm môi trường, chiến tranh làm tăng mức độ nặng của bệnh kí sinh trùng ${ }^{1,2}$. Tuy nhiên, vấn đề tổn thương tim do kí sinh trùng chưa được quan sát nhiều. Theo y văn đã được đề cập: Kean và Breslau năm 1964 lần đâu ghi nhận bệnh kí sinh trùng trong tim người, mãi đến năm 1992 mới có thêm các nghiên cứu của Tanowitz và cộng sự̂1,3. Các loại kí sinh trùng khác nhau gây tổn thương trên tim khác nhau. Chính sự đa dạng các chủng kí sinh trùng làm các tổn thương tim là không đặc hiệu và không dễ chẩn đoán.

Trước đây, người ta chỉ quan sát thấy các bệnh kí sinh trùng đặc trưng ở khu vực nhất định. Tuy nhiên do hiện tượng di dân, du lịch trong thế giới mở cũng như sự suy giảm miễn dịch do bệnh tật hay thuốc chổng thải ghép mà bệnh do kí sinh trùng có thể được tìm thấy ở bất kì khu vực nào ${ }^{1-4}$.

Bệnh kí sinh trùng đang gây ra gánh nặng lớn cho nền y tế nhiều khu vực trên thế giới, đặc biệt là các nước đang phát triển. Kí sinh trùng gây ra tổn thương ở nhiêu cơ quan trong cơ thể, như ruột, gan, não, và đặc biệt là có thể ở cá tim. Tổn thương tim do kí sinh trùng còn ít được chú ý đến hoặc không được chẩn đoán trong thực hành lâm sàng hiện nay. Tổn thương tim do nhiễm sán dây lợn thường gây u nang, có thễ gây nhầm lẫn với các loại u khác trong tim, dẫn đến sai lầm trong chẩn đoán và điều tri, có thể dẫn đến biến chứng nặng nề cho bệnh nhân.

Chúng tôi báo cáo ca bệnh này nhằm đưa ra thông báo lâm sàng về ca bệnh rất hiếm gặp cũng như cập nhật và tóm tắt các kiến thức về bệnh tim do kí sinh trùng gây ra.

\section{PHƯƠNG PHÁP NGHIÊN CứU}

Phương pháp mô tả ca lâm sàng tại bênh viện Hữu nghị Việt Đức tháng 4 năm 2021, và nhìn lại y văn về chẩn đoán và điều trị bệnh kí sinh trùng trong tim, đặc biệt là u sán dây lợn.

\section{TRƯờNG HợP LÂM SÀNG:}

Bệnh nhân nữ 51 tuổi, nghề nghiệp làm nông nghiệp, sinh sống ở trung du miên núi ở Đoan Hùng, Phú Thọ. Bệnh nhân đi khám bệnh ở bệnh viện tỉnh tình cờ phát hiện hình ảnh u trong cơ tim, chuyển bệnh viện Hữu Nghị Việt Đức. Chúng tôi thăm khám trên lâm sàng không có chèn ép tim, không có tiếng tim bất thường, không có hội chứng cận u. Trên hai bản siêu âm tim đều có khối tổ chức tăng âm, kích thước khoảng $3 \times 4 \mathrm{~cm}$, nằm ở thất phải, bám vào vách liên thất có dấu hiện cản trở đường ra thất phải nhẹ. Điểm đặc biệt trong hình ảnh khối này trên siêu âm tim là tổ chức tăng âm, mật độ khá đồng đều, không có cuống mà gắn liền gần như hòa nhập vào vách liên thất.

Chụp cộng hưởng từ tim cho thây tổn thương kích thước $35 \times 23 \times 28 \mathrm{~mm}$ ở thành vách liên thất, lồi vào trong buồng thất phải, ranh giới khá rõ với cơ thành vách liên thất. Khối giảm tín hiệu trên T1W, tăng mạnh tín hiệu trên STIR, không thấy ngấm thuốc hay tăng sinh mạch trong khối trên perfusion và cả ở thì muộn sau tiêm 10 phút, mang đặc điểm nang dịch, bờ tròn đều. 
Tổn thương không gây rối loạn vận động thành vách liên thất, chưa gây hẹp đáng kể đường ra thất phải (Hình 1).

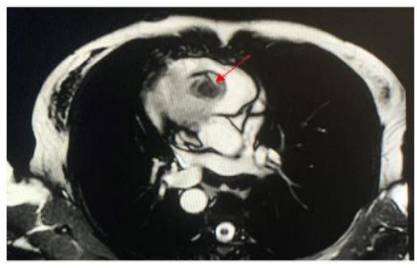

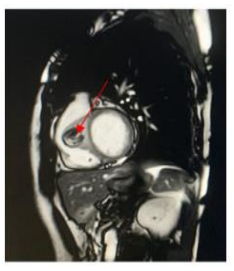

Hình 1. Phim công hưởng từ tim: $A$ - tôn thương "khối u" cắt ngang; B - tôn thương "khối $u^{\prime \prime}$ cắt dọc (múi tên chi)

Chẩn đoán u cơ tim thành thất phải, có chỉ định sinh thiết khối u qua thông tim can thiệp, được thực hiện ngày 9/4/2021. Trong quá trình sinh thiết, bệnh nhân có biểu hiện của chèn ép tim cấp, nghi ngờ có thủng thành tâm thất phải. Bệnh nhân được dấn lưu khoang màng tim, chuyển mổ cấp cứu xử trí vết thương tâm thất phải và u thất phải dưới tuần hoàn ngoài cơ thể (tim phổi máy). Đường mổ giữa xương ức. Tổn thương trong mổ: Vết thương ở mỏm thất phải, kích thước khoảng $5 \mathrm{~mm}$. Mở nhĩ phải kiểm tra: 1- Tương ứng vị trí vết thương tim không có tổn thương dây chằng van tim và cột cơ. Tiến hành khâu vết thương mỏm thất phải (chỉ prolene 4/0 có miếng đệm màng tim); 2 - Vị trí buồng thất phải - vách liên thất ở sát chân lá sau van ba lá có khối kích thước khoảng 30×35 mm, trơn nhẵn,

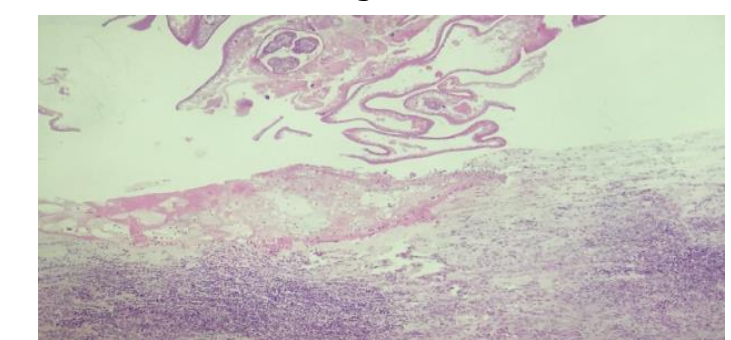

HE x 40, Hình ảnh tốn thương nang sán dây với hai thành phân: ấu trùng sán và vách nang là tố chức viêm hat.

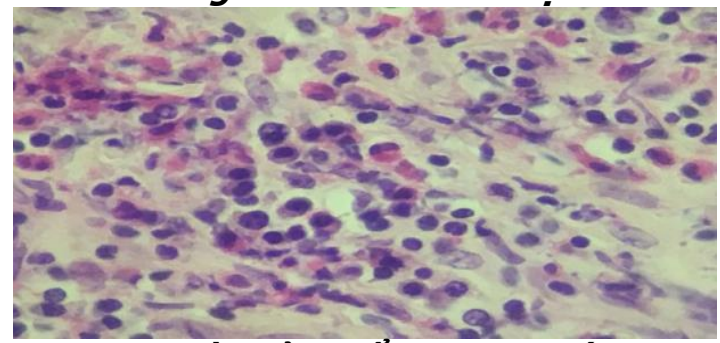

HE x 400, Hình ánh tổn thương vách nang sán dây là tổ chức viêm hạt giàu bạch cầu đa nhân ái toan. chân rộng đẩy lồi thành tim vào trong buồng thất phải. Mở khối ra bên trong khối có dịch dạng keo màu trắng trong kèm tổ chức vẩn đục màu trắng. Tiến hành lấy tổ chức trong lòng khối u, cắt bỏ vỏ u để lại phần mô cơ tim, bệnh phẩm gứi giải phẫu bệnh (Hình 2).

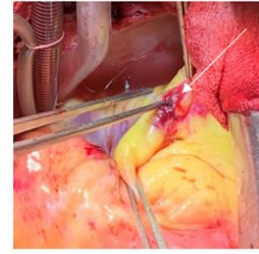

A

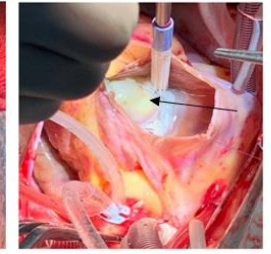

B

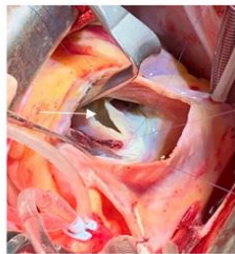

$\mathrm{C}$
Hinh 2. Tôn thương trong mổ: A: Lỗ thủng thành thất phải; B: Khối đầy lồi thành vách liên thất sang phải; C: Tố chức trong nang sau khi mơ khối (hình mũi tên chi).

Bệnh nhân chuyển về hồi sức, rút ống nội khí quản trong ngày. Siêu âm tim sau mổ không còn thấy khối trong buồng tim, chức năng cơ tim bình thường.

Kết quả giải phẫu bênh sau mổ: Tổn thương là nang sán dây với hai thành phần là ấu trùng sán dây và vách nang viêm mạn kèm tổ chức thoái hóa hoại tử, rải rác kí sinh trùng còn nhận biết được đẩu sán, lắng đọng canxi, bạch cầu ưa toan (Hình 3). Chúng tôi làm xét nghiệm huyết thanh, cho kết quả dương tính với Cysticercus cellulosae - ấu trùng của sán dây lợn (Taenia solium).

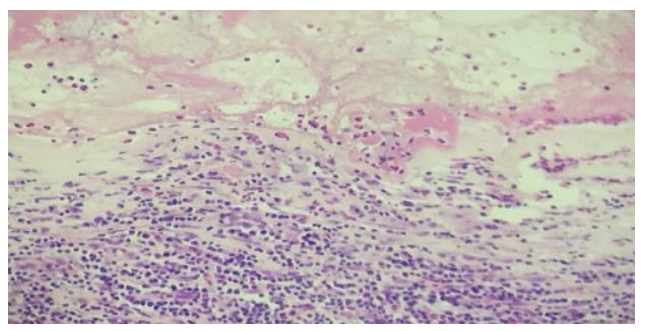

HE x 200, Hình ảnh tổn thương vách nang sán dây là tổ chức viêm hạt.

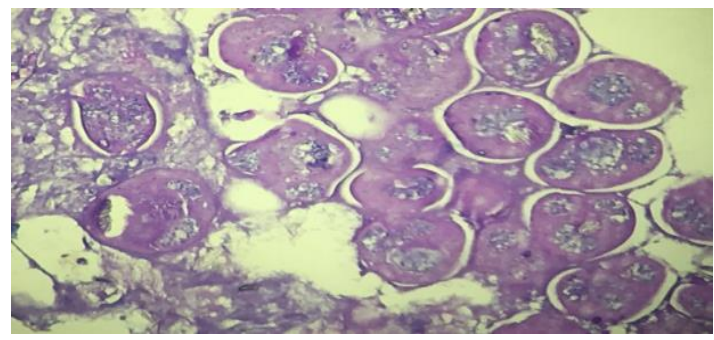

HE x 200, Hình ảnh nhiều đầu ấu trùng sán dây lợn. 

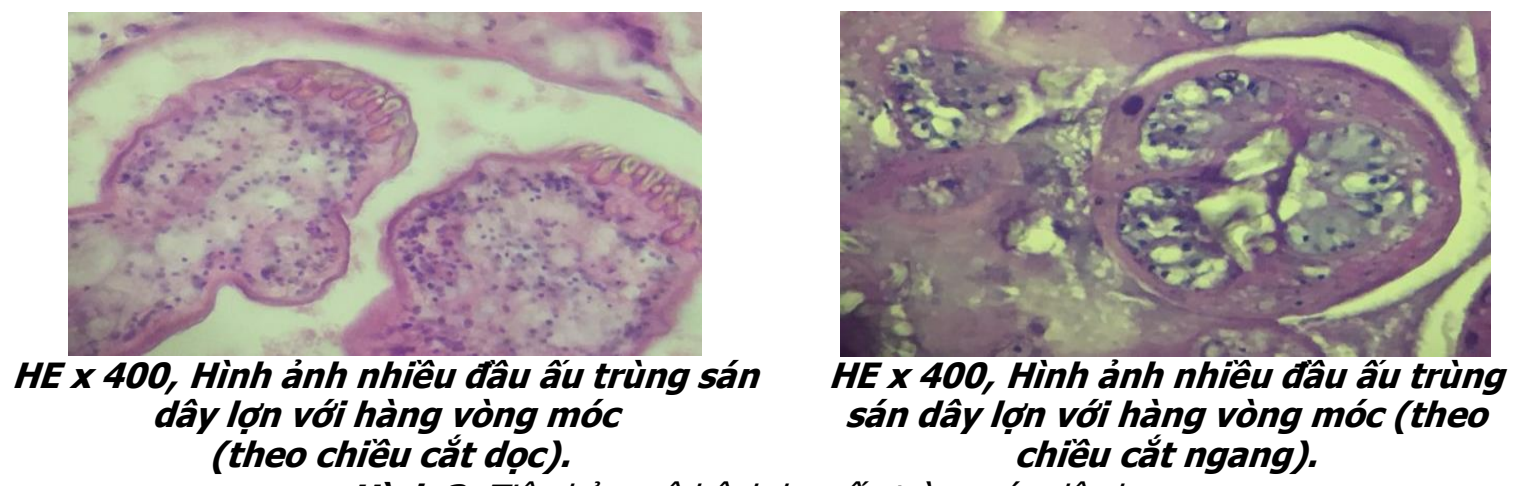

Sau khi ổn định sau cuộc phẫu thuật, bệnh nhân được chuyển bệnh viện bệnh nhiệt đới trung ương để điều trị về nhiễm kí sinh trùng.

\section{BÀN LUÂ̂N}

U tim là một loại u hiếm gặp, theo Butany tỷ lệ gặp trên tiêu bản giải phẫu là 0,001 $0,030 \%$, trong đó ba phần tư là u lành. U lành tính gồm có: u nhầy, u nguyên bào sợi, u cơ vân, u xơ, u thần kinh, u mõ. U nhầy là hay gặp nhất, chiếm đến $50 \%$, thường nằm ở nhĩ trái. U ác tính gồm có các loại u sarcom, u lympho và u di căn từ nơi khác ${ }^{5}$.

Chẩn đoán các loại u cơ tim dựa vào siêu âm tim qua thành ngực và qua thực quản, kết hợp thêm chụp cắt lớp, cộng hưởng từ và có thể cả sinh thiết cơ tim. Bệnh nhân của chúng tôi trên siêu âm phát u hiện khối u ở vách liên thất, đẩy lồi sang phải, ít di động và gây cản trở nhẹ mà chưa gây chèn ép đường ra thất phải. Vị trí và tính chất hình thái khối u nghi ngờ u ác tính. Khám toàn thân không thấy có triệu chứng của u ở nơi khác. Chúng tôi quyết định sinh thiết khối u qua can thiệp mạch để làm chẩn đoán cho bệnh nhân. Sinh thiết cơ tim qua đường tĩnh mạch dưới hướng dẫn siêu âm và chụp mạch được khuyến cáo ${ }^{5,6}$. Khi có biến chứng thủng thành thất, chèn ép tim cấp, bệnh nhân được phẫu thuật tim phổi máy xữ lý biến chứng và khối u tim cùng thì. Giải phẫu bệnh khối u cho kết quả sán dây lợn (Cysticercus cellulosae).

Tổn thương tim do sán dây lợn rất hiếm gặp. Theo những báo cáo của Bhalla và Sharma, những ca bệnh sớm nhất được mô tả là vào năm 1912 bởi các sĩ quan y tế của Quân đội Hoàng gia Anh đóng tại Ấn Độ đã mô tả một trường hợp lính Anh bị phù nề các cơ ở chi, co giật động kinh, rối loạn tâm thần và có xuất hiện các nốt ở dưới da lan rộng ${ }^{4,8}$. Sau đó cho đến năm 2006 mới có khoảng gần 40 trường hợp được báo cáo bởi Wadia và cộng sự̂t. Ở Việt Nam chưa có nghiên cứu nào về bệnh sán dẩy lợn trên người mà có liên quan tới tim, mặc dù tỉ lệ sán dây lợn ở lợn cũng chiếm một tỷ lệ nhất định.

Về bệnh nguyên của bệnh ấu trùng sán lợn (Cysticercosis) là do những ấu trùng sán lợn ký sinh ở trong cơ, trong não, trong mắt người gây nên, còn bệnh sán dây (Taeniasis) là do sán dây trưởng thành ký sinh trong ruột gây nên, trong đó có sán dây lợn T. solium. Sán dây lợn là nguyên nhân nhiếm kí sinh trùng hàng đầu, gây ô nhiễm thực phẩm cho con người theo đánh giá của $\mathrm{FAO}$ và WHO năm $2012^{9}$. Tỉ lệ sán dây lợn cao ở những nước có đàn lợn nuôi trồng kém vệ sinh. Một vài ca thì phát hiện ở các nước phát triển, do sự di dân. Bệnh nhân của chúng tôi có địa chỉ cư trú ở vùng trung du miền núi phía Bắc, làm nghề nông nghiệp, ở trong vùng dịch tễ của sán dây lợn. Theo Nguyễn và Dermauw, Việt Nam có 50/63 tỉnh có ghi nhận bệnh sán dây lợn, với tỉ lệ lợn bệnh là $0,04 \%$ ở Hà Nội, $0,03 \%$ ở các tỉnh phía bắc và $0,09 \%$ ở các tỉnh phía nam.

Chu kì sinh học của sán dây. Người có thể là vật chủ chính, vật chủ phụ hay cả hai loại của sán dây lợn. Sán trưởng thành kí sinh ở ruột non của người, rụng đốt già theo phân ra ngoại cảnh, mỗi đốt có thể chứa 5000-6000 trứng sán, chúng tồn tại lâu dài trong nước, đất, hoa màu. Lợn nhiễm sán khi ăn phải vật có đốt sán, hoặc trứng sán từ đốt sán võ̃ ra. Âu trùng sán đến ruột non, chui qua thành ruột vào hệ thống tuần hoàn lợn, đi đến cơ, tạo thành một nang có vỏ bọc ngoài, còn được gọi là "gạo lợn" (Cysticercosis cellulosae). Người ăn phải thịt lợn chứa nang ấu trùng " lợn gạo" còn sống, dưới tác dụng của dịch tá tràng, đầu sán thoát ra khỏi nang bám vào niêm mạc ruột, lớn lên phát triển thành sán trưởng thành, hoặc nang san có thể đi dòng máu đến cư trú ở bất kỳ tạng nào trong cơ thể người (Hình 4). 


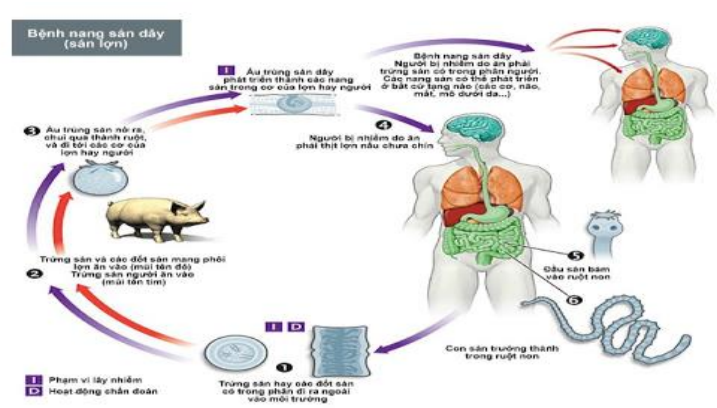

Hình 4: Vòng đời sinh học của sán dây T.solium

Âu trùng sán dây lợn gây tổn thương não là biến chứng được đánh giá là nặng nề nhất, hay gặp nhất, ngoài ra còn có tổn thương ở nhãn cầu, lách, da, cơ, phổi và tim. Ấu trùng có thể không có triệu chứng gì trong nhiều năm, chờ đến khi có cớ hội khi có sự suy giảm miễn dịch ở cơ thể vật chủ.

Chẩn đoán u tim do kí sinh trùng nói chung và sán dây nói riêng rất khó khăn. Chẩn đoán dựa trên dịch tễ học và huyết thanh học gợi ý1,7. Ca bệnh của Spina có triệu chứng lâm sàng rõ, có sốt cao, tổn thương ở da, các tạng gan, lách. Bênh nhân của chúng tôi không có biển hiên lâm sàng, trên chẩn đoán hình ảnh không phát hiện tổn thương nào khác ngoài tim ${ }^{7}$. Ở những bệnh nhân có nhiễm kí sinh trùng xét nghiệm máu có tăng bạch cầu đại thực bào và bạch cầu ưa axit. Bệnh nhân của chúng tôi hồi cứu lại thấy có số lượng bạch cầu $8,2 \mathrm{G} / \mathrm{L}$ (bình thường 4-10G/L), trong đó trung tính $45,2 \%(35-75 \%)$, ưa axit $12 \%(0-6 \%)$. Dấu hiệu tăng bạch câuu ưa axit bất thường cũng là một chỉ điểm của nhiễm kí sinh trùng cần lưu ý. Mức tăng bạch cầu ái toan ngoại vi chỉ rõ rệt trong trường hợp một $u$ nang bị rò rỉ, thâm nhiễm, nên độ nhạy và độ đặc hiệu của xét ngiệm máu cũng thay đổi theo vị trí và giai đoạn nhiễm trùng ${ }^{1}$.

Các xét nghiệm tìm kháng thể trong máu, nếu được làm, là tiêu chuẩn vàng cho chẩn đoán có kí sinh trùng trong cơ thể. Xét nghiệm có thể sử dụng phương pháp ELISA phát hiện kháng thể hoặc PCR tìm gen kí sinh trùng ${ }^{1,4,7}$.

Siêu âm tim có thể đóng một số vai trò trong xác định nang tim và đôi khi xác định hình thái u nang phù hợp với bệnh cysticercosis khi kiểm tra sức khỏe cho các bệnh nhân vì nguyên nhân khác. Hình thái khối trên siêu âm tim khá đă̆c biệt có thể góp phần định hướng chẩn đoán phân biệt với các loại u tim người lớn ở các đặc điểm: Myxomas là loại u tim lành tính phổ biến nhất $(50 \%)$ và thường ảnh hưởng đên phụ nữ trung niên. Vị trí thường gặp: tâm nhĩ trái
(75\%), tâm nhĩ phải (23\%), hiếm khi ở tâm thất; thường nối với vách liên nhĩ bằng một cuống hẹp và thường có khả năng di động. Lipoma (10 $20 \%$ u tim lành tính) thường gặp nhất ở tâm thất trái, tâm nhĩ phải và vách ngăn tâm nhĩ. Lipomatous hypertrophy (u ngyên bào sợi) $(8 \%)$ thường gặp nhất liên quan tới van tim ${ }^{16}$. Có 2 loại u có thể có hình ảnh siêu âm gần tương tự là Fibroma (u xơ) và Hemangioma (u máu). U xớ phổ biến ở trẻ em và thường có nốt vôi hóa trung tâm. U máu thường có xu hướng phát triển vào khoang tâm thất và $30 \%$ trường hợp có nhiều u cùng lúc.

Chụp cộng hưởng từ tim (MRI) cũng có thể phát hiện tổn thương do ấu trùng sán dây lợn gây ra. Tổn thương có dạng nang thuần nhất, giảm tín hiệu trên $\mathrm{T} 1 \mathrm{~W}$, tăng tín hiệu trên $\mathrm{T} 2 \mathrm{~W}$, STIR. Đầu sán là nốt đồng hay giảm tín hiệu trên $\mathrm{T} 2 \mathrm{~W}$, đồng tới tăng tín hiệu nằm trong cấu trúc dịch giảm tín hiệu trên T1W. Sau tiêm thuốc đối quang từ, tổn thương không ngấm thuốc tạo tương phản rõ với mô xung quanh. Hình ảnh dạng đầu sán trong nang trên cộng hưởng từ sẽ là gợi ý rất lớn để chẩn đoán tổn thương do sán.

Ngoài ra cần lưu ý là hầu hết các bệnh nhân bị bệnh nang sán lợn không có $T$. solium kí sinh trong ruột của họ nên xét nghiệm phân thường không cho kết quả. Các tác giả trên thế giới cũng đề nghị chụp não cho các bệnh nhân có nhiễm sán do sự thường gặp tổn thương não của bệnh này ${ }^{1,3,4}$. Liên quan đến tim trong bệnh nang sán là được cho là hiếm gặp, nhưng các nghiên cứu khám nghiệm tử thi đã cho thấy tỷ lệ hiện mắc từ 20 đến $25 \%$ ở những bệnh nhân mắc đồng thời được ghi nhận bệnh u sán thần kinh ${ }^{1}$.

Hiện trên y văn chưa có khuyến cáo rõ ràng cho điều trị u nang tim do sán, do sự hiếm gặp của bệnh, các đề nghị được đưa ra chủ yếu dựa theo kinh nghiệm điều trị của các tác giả trong bệnh cảnh nhiếm kí sinh trùng nói chung. Các nghiên cứu đều cho rằng điều trị thuốc kí sinh trùng cũng như thuốc chống viêm là phù hợp cho loại tổn thương này. Albendazol, praziquantel là thuốc đâu tay. Ngoài ra các tác giả cũng khuyến cáo sử dụng thêm corticoid phối hợp nhằm làm giảm biểu hiện của tình trạng viêm nhiễm, đặc biệt là ở tim ${ }^{13,4,7,8}$. Spina sử dụng phác đồ prednisone liều cao (1 $\mathrm{mg} / \mathrm{kg} / \mathrm{ngày}$ ) trong 15 ngày, sau đó dùng đường uống albendazole 400 mg x 2 lần/ngày/15 ngày sau đó, chụp lại MRI sau 9 tháng thì không còn tổn thương ở tim ${ }^{7}$. Với nhiễm ấu trùng sán lợn ở não và cơ, Bhalla sử dụng prednisolon 1 $\mathrm{mg} / \mathrm{kg} / \mathrm{ngày}$ trong 7 ngày, sau đó albendazol 15 
$\mathrm{mg} / \mathrm{kg} / 30$ ngày ${ }^{4}$. Theo Sharma, với ca bệnh nang sán ở tụy, các thuốc tẩy giun sán như praziquantel (10-15 mg/kg/ngày cho 6-21 ngày) và albendazole $(15 \mathrm{mg} / \mathrm{kg} / \mathrm{ngày}$ trong 30 ngày) giúp giảm tổn thương do ký sinh trùng, những thuốc này đẩy nhanh sự chết của các u nang, mặc dù u nang chết có thể xảy ra ngay cả khi không điều trịi? .

Phẫu thuật có thể được chỉ định theo khuyến cáo của các tác giả khi mà tổn thương tim có liên quan đến đường ra của buồng tim (tâm thất).

Bệnh nhân của chúng tôi ban đầu chưa nghĩ đến chẩn đoán tổn thương tim do kí sinh trùng nên có chỉ định sinh thiết khối u tim theo hướng nghi ngờ một u ác tính trong tim. Sinh thiết chẩn đoán được khuyến cáo cho những trường hợp đặc biệt như ca bệnh này ${ }^{5,6}$. Việc phẫu thuật cho bệnh nhân là bắt buộc do tai biến của quá trình sinh thiết cơ tim và qua đó chúng tôi đã xử lý luôn tổn thương "khối u tim" cho bệnh nhân và làm giải phẫu bệnh sau mổ cho kết quả như Hình 3. Điêu trị chống kí sinh trùng được thực hiện ngay khi có kết quả từ mẫu bệnh phẩm. Sau 3 tháng kiểm tra lại, bệnh nhân hoàn toàn bình phục, không có triệu chứng lâm sàng, cũng như âm tính trong các xét nghiệm huyết thanh học.

\section{KẾT LUÂN}

U nang cơ tim nói chung và do kí sinh trùng nói riêng là một tổn thương rất hiếm gặp. Chẩn đoán phân biệt trước mổ cần được nghĩ đến nhất là ở những trường hợp u tim ở vị trí bất thường với tính chất hình ảnh đặc trưng và yếu tố dịch tễ có tính chất gợi ý. Nên làm thêm xét nghiệm huyết thanh học ở những trường hợp nghi ngờ. Điều trị nội khoa thuốc chống kí sinh trùng cho kết quả tốt.
TÀI LIẸU THAM KHẢO

1. Hidron A, Vogenthaler N, Santos-Preciado JI, Rodriguez-Morales AJ, Franco-Paredes C,

Rassi A. Cardiac Involvement with Parasitic Infections. Clin Microbiol Rev. 2010;23(2):324-349. doi:10.1128/CMR.00054-09

2. Lescano AG, Garcia HH, Gilman RH, et al. Taenia solium Cysticercosis Hotspots Surrounding Tapeworm Carriers: Clustering on Human Seroprevalence but Not on Seizures. PLoS Negl Trop Dis. 2009;3(1):e371. doi:10.1371/ journal. pntd.0000371

3. Nunes MCP, Júnior MHG, Diamantino $\mathbf{A C}$, Gelape CL, Ferrari TCA. Cardiac manifestations of parasitic diseases. Heart. 2017;103(9):651-658. doi:10.1136/heartjnl-2016-309870

4. Bhalla A, Sood A, Sachdev A, Varma $V$. Disseminated cysticercosis: a case report and review of the literature. J Med Case Reports. 2008;2:137. doi:10.1186/1752-1947-2-137

5. Butany J, Nair V, Naseemuddin A, Nair GM, Catton C, Yau T. Cardiac tumours: diagnosis and management. Lancet Oncol. 2005;6(4):219-228. doi:10.1016/S1470-2045(05)70093-0

6. Cooper LT, Baughman KL, Feldman AM, et al. The role of endomyocardial biopsy in the management of cardiovascular disease: a scientific statement from the American Heart Association, the American College of Cardiology, and the European Society of Cardiology. Endorsed by the Heart Failure Society of America and the Heart Failure Association of the European Society of Cardiology. J Am Coll Cardiol. 2007;50(19):19141931. doi:10.1016/j.jacc.2007.09.008

7. Spina R, Sandaradura I, Puranik R, Lee AS. Cardiac cysticercosis. Int J Cardiol. 2013; 168(1):557-559. doi:10.1016/j.ijcard.2013.01.183

8. Sharma $R$, Neogi $S$. Isolated pancreatic cysticercal cyst presenting as a diagnostic challenge: diagnosis and treatment review. BMJ Case Rep. 2015; 2015:bcr2015210774. doi:10.1136/bcr-2015-210774

9. Ng-Nguyen D, Stevenson MA, Traub RJ. A systematic review of taeniasis, cysticercosis and trichinellosis in Vietnam. Parasit Vectors. 2017;10(1):150. doi:10.1186/s13071-017-2085-9

\section{ĐĂC ĐIỂM HÌNH ẢNH TỔN THƯƠNG ĐộNG MACH VÀ PHÂN LOẠI YOUNG BURGESS VÕ̃ KHUNG CHÂ̂U TRÊN CẮT LỚP VI TÍNH}

\section{TÓM TẮT.}

Mục tiêu: nghiên cứu đặc điểm hình ảnh tổn thương động mạch liên quan với phân loại Young-

${ }^{1}$ Trường Đại học Y Hà Nọi,

²Bênh viện Hữu nghi Việt Đức

Chịu trách nhiệm chính: Nguyễn Duy Hùng

Email: nguyenduyhung_84@yahoo.com

Ngày nhân bài: 9.6 .2021

Ngày phản biên khoa hoc: 2.8.2021

Ngày duyệt bài: 10.8 .2021
Nguyễn Duy Hùng1,2, Trương Quang Đạo

Burgess trên cắt lớp vi tính (CLVT) đa dãy trong chấn thương vỡ khung chậu (VKC). Đối tượng và phương pháp nghiên cứu: Từ $7 / 2019$ đến $11 / 2020,30$ bênh nhân (BN) chấn thương VKC, được chẩn đoán tổn thương động mạch trên CLVT và được điều trị bằng can thiệp mạch số hóa xóa nền (DSA) tại bệnh viện Việt Đức. Các đặc điểm về phân loại Young - Burgess trong chấn thương khung chậu, vị trí và hình thái tổn thương động mạch trên CLVT được mô tả. Kết quả: Tổn thương khung chậu chủ yếu là tổn thương nén bên (LC) với $28 \mathrm{BN}$ (nhiều nhất là LC-II 50\%). Có 17 $\mathrm{BN}$ có tổn thương tại 1 vị trí và $13 \mathrm{BN}$ có tổn thương 